\title{
The Efficiency Test Under Competition Law and Regulation in the Small Distant Open Economy that is New Zealand
}

\author{
Lewis Evans \\ Professor of Economics \\ and \\ Research Fellow of the New Zealand Institute for the Study of Competition and \\ Regulation \\ (Victoria University of Wellington)
}

\begin{abstract}
This paper considers the application of competition law and price regulation in the very small, and isolated economy that is New Zealand. It argues that the total surplus (efficiency) criterion should be applied in tests of practices and actions where the competition threshold is not met or doubtful. Further, it argues that this criterion is admitted, if not required, under New Zealand statutes. The differential treatment of affected parties, including foreign investors, in measuring the surplus is considered.
\end{abstract}

JEL Classification: D61,K21, K23, L4

Forthcoming: New Zealand Economic Papers 38(2), December 2004

Acknowledgements: This paper has benefited from the comments of Mark Berry, James Mellsop and Andy Nicholls. Jason Varuhas and Richard Robinson provided research assistance. 


\section{Introduction}

The purpose of this paper is to examine the case for an efficiency test in competition and regulatory policy, particularly in the context of the geographic isolation, small size and openness of the New Zealand economy. The efficiency test requires implementing a costbenefit analysis of the relevant transaction, practice or regulatory restriction. Following enjoinment by the High Court ${ }^{1}$ for it to use empirical evidence and Ministerial requests for evaluation of regulatory actions, the Commerce Commission has conducted a number of quantitative cost-benefit studies. The various approaches of these studies make it timely to consider whether, and if so how, cost-benefit analyses should be implemented in principle and under New Zealand competition law statutes. ${ }^{2}$

Competition and regulatory policy is encapsulated in the Commerce Act 1986 and its amendments, the Telelcommunications Act 2001, and the Dairy Industry Restructuring Act 2001. ${ }^{3}$ The economic precepts underlying the Commerce Act 1986 were in substance taken from the Australian Trade Practices Act 1974, which in turn drew heavily (but not exclusively) on United States anti-trust law. However the United States is an economy of some 300 million people. In contrast, New Zealand has an economy of 4 million people, roughly the population of Sydney. Are concepts developed in the context of a large economy such as that of the United States, or even Australia, applicable without modification in a small isolated economy such as New Zealand? Certain country-specific characteristics - for example, population and geographic isolation - are exogenous to the operation of competition law and regulation. However others such as market structure and firm performance are much less so, being moulded to a degree by these legal constraints as well as by the country's given features and openess to trade; itself a policy choice. Relative to these larger economies and many other developed economies the New

\footnotetext{
$1 \quad$ Telecom Corporation of New Zealand Limited v Commerce Commission (1991) 4 TCLR; 446.

2 These include the Commission's Determinations regarding a proposed arrangement between Air New Zealand and Qantas (Commerce Commission Decision 511 (2003)) and joint marketing of Pohokura gas (Commerce Commission Decision 505 (2003)), and gas pipeline (Commerce Commission Section 56 Gas Control Inquiry: Final Report (2004)) and unbundling enquiries.

The term Commerce Act shall be used for the Commerce Act 1986 and its subsequent amendments.
} 
Zealand economy generally has very high industry concentration, high capital intensity across many industries, high total cost to revenue (with smaller firms having a relatively higher ratio than larger firms); and significant lack of benefits of scale. ${ }^{4}$

New Zealand's small, geographically isolated economy renders foreign markets of direct relevance to its own markets' performance. The effects of distance on trade and of the interaction of distance and border factors on an economy's performance are difficult to assess, and yet they are important in establishing what might be expected of internal and external trade of an isolated economy. The vigour of international trade affects the extent of competition in domestic markets; even their definition. Because of transaction costs and arguable networking dislocations implied by geographic isolation, New Zealand has a separation of its domestic market from other markets to an extent not experienced by many other countries. ${ }^{5}$ Despite the breadth of the Tasman Sea, open access to the markets of its relatively large near neighbour, Australia, is extremely important for New Zealand trade per se, and for the competition it poses for the New Zealand domestic market. The openness of the economy is important for the opportunities it presents industries for procurement and for export, and domestic competition. A growing body of literature concludes that open trade and investment policies are relatively much more important than competition law for market and firm performance in small countries. ${ }^{6}$ For those countries whose location is such that their (domestic) markets coincide geographically with those markets of larger economies were it not for trade and other institutional restrictions that relate to national sovereignty, close harmonisation of all aspects of competition law would seem appropriate, particularly if barriers to trade were low. Indeed, in the absence of such barriers economies of scale and scope will be enhanced by low-cost exporting as will market discipline effects of imports. The small economy problem may not apply for countries geographically and institutionally close to much

\footnotetext{
$4 \quad$ The issues and quantification of the New Zealand economy's small size, geographic isolation and openness are discussed in Ratnayake (1999), Arnold, Boles de Boer, and Evans (2003), and Evans and Hughes (2003).

$5 \quad$ Although, in regard to the United States, Krishna (2003) finds no correlation between trade and welfare arising from either distance or income relating to any of the United States' trading partners, this is unlikely to be applicable to an isolated economy such as that of New Zealand.

$6 \quad$ See for example, Levisohn (1993) and Hoekman, Kee and Olarreaga (2001), and Trebilcock (1991, and 2004). For a skeptical view of the evidence see Baldwin (2000).
} 
larger economies, no matter how small the economy. A small European country might efficiently harmonise its law closely with the competition law of large neighbours (and ultimately even be embedded in the European Union) whereas New Zealand and Australia face some disjunction between their domestic and export markets due to costs associated with distance. For Australasia close harmonisation of law with other countries or more restrictive competition law may be less efficient.

What is meant by efficiencies and its link with cost-benefit analysis are considered in the next section. The application of competition law in New Zealand is discussed in Section 3. Although competition law is different from price regulation in that a) it relies on sanction by Courts rather than the dictates of appointed officials, and b) price regulation is predominantly applied to infrastructure (nontradable goods for which the size and isolation of the economy may have less import), the principles relating to efficiencies and market performance are the same. The extension to regulation is mentioned in this section. In Section 4 the case for an efficiencies defence is reviewed.

\section{The Efficiency Defence and Cost-Benefit Analysis}

Competition law has the purpose of regulating commercial conduct in the sector of the economy for which there is competition and de-centralised production and consumption decisions. It affects the balance of co-operation and competition among commercial firms and limits their practices. Particularly in small economies, there is a trade-off between numbers of firms and economies of scale that competition policies should reflect. The tension between scale and numbers of firms is aggravated by geographic isolation.

Firms evolve in all sorts of ways: via competition in the product and ownership markets and by arrangements with other firms seeking to attain improvements in productive efficiency and scale. In small economies, however, the extent to which such efficiencies can be achieved may be limited by the size of the domestic market, thereby limiting 
economies of scale and scope ${ }^{7}$, and raising transaction costs in which there are savings associated with specialisation that attends larger market sizes. ${ }^{8}$ The alternative for tradable goods and services in small economies is to expand by exporting. Caves, Porter and Spence (1980) argue that the small country handicap is manifest in sources of economic performance. ${ }^{9}$

Economic performance can be divided into two broad categories. Firstly, allocative efficiency is static or timeless in that it typically does not incorporate the process of investment and innovation, nor the concomitant management of risk. It is measured by total economic surplus at points in time. ${ }^{10}$ It includes intra-firm allocative efficiency often termed productive efficiency or x-efficiency - which affects the ability of a firm to produce output at minimum cost. Productive and, consequently, allocative efficiency are affected by the principal-agent issues that attend decision making under asymmetric information in uncertain environments that, together with demand and cost characteristics, motivate different institutions. ${ }^{11}$ They are intrinsic to economic activity and although they may be economised under particular institutional arrangements, they cannot be eliminated. For this reason the highest achievable (allocatively) efficient outcome, is necessarily constrained, or second-best, efficient.

The second category is dynamic efficiency. It can be measured as the present value of total surplus into the future, where investment and innovation are explicitly recognised. Because it is forward-looking it should recognise uncertainty associated with demand and

\footnotetext{
$7 \quad$ Where the costs of producing two or more products jointly are less than the costs of producing them separately.

$8 \quad$ See Stigler (1951).

$9 \quad$ Gal (2001) reports that studies of manufacturing industries in small economies show a considerably larger fraction of all output is produced at less than minimum effficient scale.

10 Total economic surplus is the total willingness to pay of consumers less the total cost of production, or the sum of producers' and consumers' surplus. Consumers' surplus is measured as the area under the demand curve and above the unit price. The concept of consumers' surplus relies on the fact that, under some assumptions (for example, an absence of income effects is sufficient), the market demand curve shows the welfare of various increments of output (see Mas-Colell, Whinston, and Green (1995), s.10c), for issues in this interpretation). Where the market demand curve consists of firms there are, of course, no income effects to be considered. Producers' surplus is calculated in a symmetric way, as the amount the producer receives over and above the minimal payment that enables it to supply, and has an analogous interpretation (see Mishan (1963)).

$11 \quad$ See Hansmann (1996) and Jensen and Meckling (1976) for reviews of institutional design in the context of agency issues.
} 
cost and its relationship to investment and innovation. Investment and innovation are key to achieving dynamic efficiency, and they require that attention be paid to the incentives and barriers relating to the dynamic process of investment and innovation. Both economic arguments and empirical studies of the literature confirm dynamic efficiency gains are more important for social welfare than static efficiency gains. ${ }^{12}$ Goolsbee (2000), for example, stresses that delayed innovation and investment lead to missing markets where both consumers' and producers' surplus are missing. The welfare loss from a missing market may swamp allocative efficiency effects pertaining to existing markets, or existing levels of investment. Goolsbee op cit and Hausman (1997) for different cases find very substantial welfare losses arising from delayed markets caused by regulatory settings.

It should be apparent that evaluations of static and dynamic efficiency of an action or practice simply entail the application of long established principles of cost-benefit analysis in the comparison of "factual" and "counterfactual" situations. ${ }^{13}$ In a seminal article, Williamson (1968) tied cost-benefit analysis to competition law in proposing that, as a general matter, a horizontal merger could benefit an economy if it allowed the firms to achieve "efficiency gains" - in his case, a reduction in their per-unit operating costs even in the presence of an increase in price. Because these efficiency gains allow any given level of output to be produced with fewer inputs, such a merger would free up resources that could be used in other industries and potentially lower prices to consumers in those markets. In essence, Williamson argued for, what is now known in the legal profession as, an "efficiencies defense", for mergers and commercial practices that increase total surplus.

\footnotetext{
12 The classic reference on static efficiency is Harberger (1954) who estimated that the total welfare loss due to market power is no larger than 0.1 percent of GNP. A potential counter-argument to Harberger's estimate is provided by the theory of rent seeking. It suggests that, in cases where a firm has an ability to capture an oligopoly or monopoly rent, economic agents have an incentive to compete for it. This competition can involve economically wasteful activities such as lobbying, unnecessary litigation or even crime (e.g. bribery). The form of such competition will depend upon the nature of barriers to entry.

${ }_{13}$ The principles of cost-benefit analysis have been established for some 30 years (see Mishan (1988) for a review)
} 
The background to Williamson's paper was the observation that in the US, mergers were challenged by antitrust authorities if they held the prospect of higher prices. Katz (2004, 19) argues that this price threshold was implemented in the past by public policies that sought atomistic competition (For example the Robinson Patman Act 1936 in the United States), but that such an approach is anachronistic. Katz proposes that the modern view of United States antitrust authorities is suggested by a recent decision of the United States Supreme Court that included the statement:

The mere possession of monopoly power, and the concomitant charging of monopoly prices, is not only not unlawful; it is an important element of the freemarket system. The opportunity to charge monopoly prices - at least for a short period - is what attracts "business acumen" in the first place: it induces risk taking that produces innovation and economic growth. ${ }^{14}$

It is not by chance that the consumer price threshold test was the consequence of policies that focused on "atomistic competition” for this is the basis of the textbook, static, perfect competition world, in which demand and supply are passive in terms of the actions of individual agents of any kind. It doesn't incorporate, to any useful degree of approximation, the dynamic process of the evolution of markets, and especially the markets of a small economy. The notion of "perfect" competition should not be the test of practices and transactions under competition law: static models have limitations in representing rivalry. There are many static models of few demanders and/or suppliers that relax certain assumptions of perfect competition, but many of these too fail to capture the dynamic process of competition that is paramount in the Supreme Court's statement. ${ }^{15}$ What is meant by competition is critical to what test is desirable.

The New Zealand Commerce Act 1986 does not define competition, although it does refer to "workable or effective" competition at s 3(1). Gault at CA 3.15, reviews court and tribunal interpretations and suggests the phrase has its genesis in the decision of the Australian Trade Tribunal in Re Queensland Co-op Milling Assn Ltd; Re Defiance

\footnotetext{
14 Verizon Communications Inc. vs Law Offices of Curtis V. Trinko, LLP (2004) 540 US 398, 407 Scalia J.

$15 \quad$ For example, many few-agent Cournot and Bertrand game theory models do not capture the essence of dynamic competitive processes.
} 
Holdings Ltd. (1976) 25 FLR 169; 8 ALR 481; ATPR 40-012, where it describes workable competition as including

“....mechanism for the discovery of market information and for enforcement of business decisions in light of this information.., and ... a creative role for firms in devising new product, the new technology, the more effective service or improved cost efficiency. And there are rewards as well as punishments. ..."16

The New Palgrave Dictionary of Economics $(1998,531)$ defines competition as being:

[R]ivalry between individuals (or groups or nations), and it arises whenever two or more parties strive for something that all cannot obtain.

Legal and economic meanings imply that the essence of competition is rivalry. This interpretation is linked to economic concepts by Baumol (2002) who emphasises that competition is about the process of interactions among suppliers and demanders, and that it is this process over time that engenders dynamic efficiency. There is nothing in this process that singles out price rises as indicative of declines in prospective welfare, and hence dynamic efficiency. ${ }^{17}$

The Commerce Act may not define competition per se but the Act's purpose provision (Section 1A) states:

The purpose of this Act is to promote competition in markets for the long-term benefit of consumers within New Zealand.

This is strongly suggestive of a link between the process of competition and the goal of efficiency. ${ }^{18}$ It indicates that the framers of the Act intended that the Act should promote competition, in such a way that enhances the performance of markets in delivering

\footnotetext{
16 Gault on Commercial Law, 2005, Brookers, Wellington

$17 \quad$ Fershtman and Pakes (2000), for example, describe a model in which collusion and price wars arise endogenously over time and which are necessary for efficient performance of the industry.

$18 \quad$ See also Gault op cit CA1A.05.
} 
benefits to consumers in the future. ${ }^{19}$ Thus, competition is to be the instrument, and future consumer welfare the objective, under the Commerce Act. Plainly, static welfare or welfare today are not the targets of the Act. $^{20}$

The meaning to be attached to $\mathrm{s} 1 \mathrm{~A}$ is critical because where the purpose of an act is clear, the text of that act should be interpreted to give effect to that purpose. Further, there is a legislative direction that such a purposive approach is required. The Interpretation Act 1999, s 5 provides:

\title{
Ascertaining meaning of legislation
}

(1) The meaning of an enactment must be ascertained from its text and in the light of its purpose.

(2) The matters that may be considered in ascertaining the meaning of an enactment include the indications provided in the enactment.

(3) Examples of those indications are preambles, the analysis, a table of contents, headings to Parts and sections, marginal notes, diagrams, graphics, examples and explanatory material, and the organisation and format of the enactment.

\begin{abstract}
Although the plain meaning of words in an act are the starting point, where the text benefits from clarification and when it strains to fit the purpose of an act, the purposive meaning of the act has a determinative role to play. ${ }^{21}$
\end{abstract}

19 Indeed, the basic test of the Commerce Act for commercial practices and mergers concerns whether there is likely to be a substantial lessening of competition under the relevant action. The Commission, acting under s 61(6) and s 67(3), can authorise an action which would "likely result in a benefit to the public which would outweigh the lessening of competition that would result." (emphasis added). The threshold for the test for price control under Part IV of the Act seems lesser in that it is a "market in which competition is limited or is likely to be lessened" (s 52).

$20 \quad$ Katz $(2004,56)$ argues that, in the United States the Department of Justice and Federal Trade Commission apply a similar view in antitrust law. Trebilcock (2004) surveys the continuing evolution of the Canadian position, and suggests that the interpretation of an efficiencies defence statute is not settled. It reports that a recent case (the Superior Propane Case) ultimately decided on a "balancing weights criterion" that gave an answer close to the total total surplus criterion, although in the final appeal the Commissioner sought, unsuccessfully, a weight of zero on producer surplus ( The Commissioner of Competition v Superior Propane Inc (2003) 23 cpr $\left(4^{\text {th }}\right), 316$ (FCA)). Trebilcock op cit, suggests that decisions based upon the balancing weights and total surplus will generally coincide. The controversy engendered by the Superior Propane case was stimulated by an incorrect calculation of total surplus (Mathewson and Winter (2000)), and it illustrates the arbitrary nature of weights.

21 The retrospective application of the Interpretation Act 1999, at s.4(1), implies that it is applicable to all acts, including the Commerce Act 1986. 
The purpose statement of the Commerce Act is in accord with the concept of dynamic efficiency since it treats competition as a process aimed at enhancing resource allocation, including the processes of innovation and investment, for market-determined future consumer welfare. In this context then, is the present value of total surplus a reasonable conceptual and practical criterion for the assessment of actions under the Commerce Act? If we take as given that static efficiency at any point in time is best measured by total surplus, then it is reasonable to take the present value of total surplus as the criterion for assessing alternatives under the Act. This will indicate the aggregate of net benefits resulting from resource allocation and investment and innovation processes to individuals in the economy. The question then reduces to whether or not total surplus - that is, costbenefit analysis in which benefits and costs are treated neutrally - is the appropriate criterion at any point in time; but assessed within the context of the long-term benefit of consumers.

The main class of departures from total surplus arises when different parts of the surplus are given different weights for different consumers and producers. ${ }^{22}$ Such a practice has in the past been routinely applied by the World Bank in conducting cost-benefit analyses of projects, and has been quite widely applied by the Commerce Commission. ${ }^{23}$ The World Bank's justification for the differential weighting is that of incidence of project benefits and costs. It sought to place emphasis on projects that benefited particular sections of the community in those countries the Bank offered its services to. ${ }^{24}$

\footnotetext{
22 Some weighting schemes may have the effect of counting as a net benefit a transfer among consumers and producers. Katz op cit notes that this plainly contradicts the Pareto principle. The Commission has utilized such a weighting: examples include its draft reports in the gas pipelines, and mobile termination rate enquiries.

23 The Commission has supported this approach in its Pohokura gas joint marketing authorisation (Commerce Commission Decision 505 (2003)), telecommunications unbundling (Commerce Commission Section 64 Review and Schedule 3 Investigation into Unbundling the Local Loop Network and the Fixed Public Data Network: Final Report (2003)), price control evaluation of mobile termination rates (Commerce Commission Mobile Termination Rates: Draft Report (2004)), Air New Zealand-Qantas cooperative arrangement (Commerce Commission Decision 511 (2003)) (check) and gas pipeline regulation evaluations (Commerce Commission Section 56 Gas Control Inquiry: Final Report (2004)) among others .

$24 \quad$ See Anandarup (1984). Irvin (1978, ch. 8) briefly summarises the approaches proposed to that date. The modern approach of the World Bank is to place less weight on narrow cost-benefit analysis of projects, and to focus on their governance and role in institutional evolution (World Bank (2000)) This shift to consideration of process reflects an enhanced focus on dynamic efficiency.
} 
The use of cost-benefit analysis in competition law is typically different from its common application to projects; most obviously because this law has the objective of using competition to enhance the long-term interest of consumers. Any justification of differential weighting of cost-benefit surpluses under competition law can only be based upon (long-term) incidence, or on enhancing rivalry.

Assessing any link between total surplus and the Commerce Act first requires consideration of the definition of consumers under this Act. Candidates include a) endusers, as in the Telecommunications Act 2001 (s 18) which, arguably, means any economic agent, be it firm or household that is not in the business of telecommunications, b) any consumer of goods and services, including those firms that may fall in the same industrial classification, as a practical matter this is the definition used in competition law and, often in, regulatory cost-benefit analysis c) "final consumers" being the position of individuals or households as consumers, producers and factor suppliers, or d) the "final demands”, that is the consumption of consumers. Given that it is the long term interest of consumers that matters, and the fact that this entails good performance in all relevant markets no matter how narrow the ultimate objective, cases a) and b) can be viewed as intermediate to cases c) and d).

If consumers means "final consumers" as individuals and households they are producers, suppliers of factors of production, and final consumers: the welfare of consumers is determined by all of these activities and to distinguish among them in any category under competition law would require identifying long term incidence, including the effect of the transfer process itself. There are several reasons to conclude that the cost-benefit surpluses should be treated neutrally.

\subsection{Incidence}

First, the difficulty in assessing incidence is well known, and renders moot the utility of attempting any assessment, yet without knowing incidence across households and 
individuals the welfare effect of differential weighting cannot be established. ${ }^{25}$ Assessment of incidence in a static setting conceptually requires inversion of a detailed general equilibrium model that is generally not possible. Static incidence is particularly difficult to evaluate when consuming units may be firms, individuals and households. These difficulties are materially enlarged when the long-term benefit of consumers is considered; for then the effects of, and on, investment and innovation have to be assumed and worked through in order to estimate incidence given that long-term benefit is the goal of the Act.

If differential weighting among consuming and producing units were to be the province of decisions under competition law then it might be expected that the statute provide the relevant guidance as to differential weighting, however it does not. ${ }^{26}$ The state has other institutions of taxation, social welfare and direct provision that it uses to affect income redistribution. ${ }^{27}$ The inability to estimate incidence suggests that these more direct methods of transfer by the state are much more efficient ways to target households and individuals for income redistribution, thus it is not surprising that criteria for transfers are not provided in competition law statutes.

A second interpretation of the Act would be that New Zealand competition law does discriminate in that it seeks the enhancement of the benefit of consumers in their role as "final demanders" per se. This is a narrower goal and one more difficult to justify for welfare gains than that of consumers per se. Nevertheless, treating final consumption as the desirable target does not imply different weights among consumers and producers and factor owners at any point in time. If competition law is to be implemented for the longterm benefit of final consumption then processes of efficient investment and innovation must be enabled. The effect of any differential weighting of elements of total surplus for the competitive process will affect the welfare of final consumption. It will also affect

\footnotetext{
${ }^{25}$ See Mishan (1988, 201-202, 210-211).

${ }^{26}$ It is considered below whether Part 1A of the Act, in particular its reference to "consumers within New Zealand", and the reference in Part 4 of the Act to "benefits to acquirers" imply discrimination among producers and consumers in surplus calculations.

${ }^{27}$ It is a long established cost-benefit analysis proposition that where the income distribution is optimal, perhaps as a result of tax and social welfare policies, or price changes are small that total surplus accurately represents welfare changes.
} 
long-term incidence between consumers, as consuming, producing and factor supply agents that would again be virtually impossible to unravel. ${ }^{28}$ The unpredictability of incidence under any interpretation and the lack of a rationale for, and statutory specification of, unequal weighting of surpluses under competition law suggest that any rationale for non-neutrality in the treatment of surpluses must lie with its effect on the competitive process.

\subsection{The Process of Competition}

It is common in cost-benefit to calculate the surplus from a sequence of snapshots of markets in (perhaps temporary) equilibria into the future. Such a sequence assumes a concomitant investment and innovation profile, although commonly the investment process is not modelled. The incentives for investment and innovation relate to the ability to make and retain profit; thus profit has the dual roles of incentivising and enabling investment, and providing the asset owners with utility. Because the cost-benefit analysis is forward looking there is also considerable uncertainty relating to a wide range of factors extending from the business cycle to entry and technical change. The profit inducement to rivalry and the uncertainty that attend investment and innovation renders determining a level of profit that will prospectively reward and enable investment extremely difficult. ${ }^{29}$ To down-weight profit in the application of competition law is to reduce incentives for competition in product and ownership markets, entry and investment in that industry: that is, reduce rivalry. ${ }^{30}$ The literature (see Baumol (2002), Shapiro (2002) and CRA(2002) for the case of the new economy in particular) suggests that the efficient development of industries requires the removal of barriers to entry rather

$28 \quad$ For example, consider the challenge of determining incidence of a missing market between consumers and producers.

29 That even the volatility - let alone the mean - of profits has an important effect on investment decisions is apparent from the literature on price cap regulation (see, for example, Evans and Guthrie (2005) and Dobbs (2004)).

30 Setting aside incidence, any assessment of benefits to the competitive process associated with placing a lower weight on profit, is not indicated by the magnitude of transfers resulting from differential weighting of surpluses: rather it would consist of the present value of the change in total surplus into the future that would be a consequence of these weights. 
than concern with the level of a market's concentration. Evans and Schmalensee (2001,

47) explain it in this way:

In particular, the analysis of market power in new economy industries must consider the vulnerability of leading firms to entry powered by drastic innovation, not just to the entry of firms producing equivalent products with known processes. Analysis of this sort of fragility may require difficult judgements about the likelihood of disruptive innovations in the future, but simply to assume such innovations cannot occur is to ignore history and to impart substantial and obvious bias to market power analysis in important sectors.

The absence of a positive link between the act of down-weighting producers' relative to consumers' surplus, and rivalry, when taken together with the purpose of the Act suggest that there is no rationale for non-neutral treatment of producers' and consumers' surplus. 31

In the context of a small open economy equally weighting consumers' and producers' surpluses, and thereby utilising a total surplus standard, is particularly important. To do otherwise would jeopardise the ability of the economy to achieve even the limited scale economies that its industries are capable of. ${ }^{32}$ The point has even more force when it is recognised that in many industries of a small economy scale economies can only be achieved by exporting. The calculation of total surplus in a small open economy in industries where a large fraction of output is exported entails applying the total surplus calculation to both the domestic and foreign markets. Particularly where export prices are exogenous it may be that the only surplus gain of a merger or commercial practice lies in producer surplus. To ignore or ascribe a lower weight to domestic and/or (potential) export generated producers' suplus would be to inhibit activity and investment in these industries.

31 Regulation is mooted for situations where competition is limited. Some regulation has been designed with the purpose of enhancing competition; but with a debatable effect on rivalry and dynamic efficiency. Perhaps the most prominent application of regulation that seeks to enhance competition is that of access regulation as applied to deemed network natural monopolies. The outcomes do not clearly suggest that the long term interest of consumers is enhanced since they reflect a trade-off between competition in downstream markets at the cost of limiting competition in the regulated market (examples include Crandall, Ingraham and Singer (2004) and Boles de Boer, Enright and Evans (2000)).

32 There is literature that argues that entry (competition) can be excessive (see Evans and Hughes (2003) for discussion) in which case total surplus provides the correct basis of evaluation. 


\section{$3 \quad$ Application Under New Zealand Competition Law}

This section examines whether the references to "consumers within New Zealand" in the price control provisions of Parts 4 and $4 \mathrm{~A}$ of the Act imply discrimination among producers and consumers in surplus calculations. It is useful first to very briefly review the legal context.

The s 1A was introduced on 26 May 2001 and it implies a focus on the long-term benefit of consumers. It applies to all parts of the Commerce Act, including the price control s 52, and Part 4A which has its own purpose statement (s 57E): although s 52 makes no reference to the long-term interest. ${ }^{33}$ Its application to trade practices and mergers is covered under the authorisation process of $\mathrm{s} 3 \mathrm{~A}$ where a test enables a lessening of competition to be balanced against a benefit to the public. The benefit to the public interpreted in the light of the long-term interest of consumers suggests a (dynamic) total surplus test, providing benefit to consumers does not conflict with benefit to the public. A recent High Court decision of Hansen J and Vautier (Lay Member) found that the term benefit to the public was intentionally broader than consumers (p 240) and that the authorisation test concerns resource implications for the long term interests of consumers (p 241). ${ }^{34}$ This position admits the preceeding argument that, even if the term consumers

33 Part 4 of the Commerce Act also contains electricity lines business control regulations, which in turn contains s 57E:

The purpose of this subpart is to promote the efficient operation of markets directly related to electricity distribution and transmission services through targeted control of for the long term benefit of consumers by ensuring that suppliers-

(a) are limited in their ability to extract excessive profits; and

(b) face strong incentives to improve efficiency and provide services at a quality that reflects consumer demands; and

(c) share the benefits of efficiency gains with consumers, including through lower prices.

The statement reaffirms the goal of the long-term benefit of consumers and proposes elements of the route by which this may be achieved. Interpreted in this context this section does not disturb the proposition that total surplus over time be the criterion for regulatory interventions; it plainly does not argue for short-term transfers between producers and consumers, that have any potentiality for deleterious effects on investment and consumer-demanded quality. The counterfactual to judge "lower prices", for example, should be defined with respect to the other provisions relating to long-term efficiency gains and quality.

$34 \quad$ Legal interpretations of public benefit have focused upon a public/private dichotomy: rather than a functional difference (see Gault op cit 3A.05), in which case public benefit and the long term benefit of consumers may well coincide. 
refers to consumers in their consumption role only, that the total surplus criterion would be in their long-term interest. However, reference to the interest of consumers as including all their roles may approach very closely the notion of benefit to the public: for there can be other additional dimensions to public. ${ }^{35}$

The benefits to acquirers test arises under Part 4 of the Act where the Commerce Commission determines whether or not (a form of price) control is to be applied. Section 52 states that:

Goods or services may be controlled if-

(a) The goods or services are, or will be, supplied or acquired in a market in which competition is limited or is likely to be lessened; and

(b) It is necessary or desirable for those goods or services to be controlled either-

(i)In the interests of persons acquiring the goods or services (whether directly or indirectly), if the goods or services are acquired from a person who faces limited or lessened competition for the supply of those goods or services; or

(ii)In the interests of of suppliers, if the goods or services are supplied to a person who faces limited or lessened competition for the acquisition of those goods or services.

The reference to acquirers of the goods and services, whether directly or indirectly raises a conundrum for the Act. Plainly, in a static setting interests of acquirers may be in conflict with benefits to consumers for there is no reason why benefiting the interests of acquirers of particular goods and services, at the expense of any other provider or consumer, should enhance the aggregate welfare of consumers. However, there is nothing to suggest that the full purpose of the Act - namely long-term benefit for consumers should not be applied. Viewed in the context of the full purpose of the Act the controls under Section 52 should be applied insofar as they enhance the long term benefit of consumers. ${ }^{36}$ Under this interpretation, the interests of acquirers exist insofar as they lead to the long term benefit of consumers, wherein, on the argument adduced above for the case of the consumption of consumers, the present value of total surplus is again the

$35 \quad$ Air New Zealand and Qantas Limited v Commerce Commission, Infratil Group, Virgin Blue and Gullivers Pacific CIV 2003404 6590, 319, 422-425 (reported at [2004] 3 NZLR 550).

36 Indeed, the Commerce Commission can also make authorizations with respect to prices, revenues and quality standards pursuant to Controlled Goods or Services (Part 4), and in so doing the Commission is explicitly enjoined at s 70A to have regard to the promotion of efficiency. 
appropriate criterion. ${ }^{37}$ Most obviously, static transfers to acquirers that might arise from producer-consumer transfers associated with price control at a point in time, will not be in the long-term interests of acquirers were investment, innovation and quality to be affected.

It is thus of significance that price control (Part 4) is included in the Act. It is part of the Commerce Act and therefore should be assessed in the context of this Act. It suggests that the role of (price control) regulation is to induce "competition-like outcomes" when it is deemed that competition is not sufficient. If regulation were to be instituted for other reasons, such as the differential treatment of interest groups, a different regulatory framework would be relevant, and the role of economic analysis different because the objective would not be the long-term benefit of consumers.

In applying the statute the Commission is enjoined to conduct a public benefits test by Section $3 \mathrm{~A}^{38}$ of the Act, which provides:

Where the Commission is required under this Act to determine whether or not, or the extent to which, conduct will result, or will be likely to result, in a benefit to the public, the Commission shall have regard to any efficiencies that the Commission considers will result, or will be likely to result.

Particularly in small open economies and in some industries, some considerable fraction of economic activity may be conducted by foreign firms, and certain of the aggregate benefits of domestic commerce may rest with foreign consumers. This raises the question as to what consideration can, or should, be given to markets (consumers or producers) outside New Zealand or foreign ownership in assessing public benefits and detriments under the Commerce Act, and if considered, to what extent, if any, differential weighting should be applied in the public benefits test. The neutral treatment of consumers and producers is implicitly accepted in the recent High Court judgment of Hansen $\mathrm{J}$ and

\footnotetext{
$37 \quad$ Part 4 of the Act empowers the Commission to institute price regulation. It is part of the Commerce Act and therefore should be assessed in the context of this Act. Moreover generally, regulation is implemented for various purposes, prominent among them is satisfying the demands for particular treatment by special interest groups. The role of economic analysis is different under such regulation. ${ }^{38}$ Inserted by Section 4 of the Commerce Amendment Act 1990.
} 
Vautier (Lay Member) on an appeal against the Commerce Commission's decision to decline Air New Zealand and Qantas’ application for an alliance arrangement. ${ }^{39}$

In this consideration, it is taken as given that Section 3A refers to the public of New Zealand, domestic consumers and producers are equally weighted, and only the implications of foreign ownership of firms are considered. Foreign consumers are so diffuse and passive from New Zealand's viewpoint that their responses will not much directly affect New Zealand consumers' and producers' welfare, and hence the welfare of the public of this country. ${ }^{40}$ The position can be justified by the assumption that foreign markets for New Zealand are relatively competitive.

Section 3(1A) of the Act provides:

Every reference in this Act, except the reference in section 36A(1)(b) and (c) of this Act, to the term "market" is a reference to a market in New Zealand for goods or services as well as other goods or services that, as a matter of fact and commercial common sense, are substitutable for them.

This definition indicates that it is markets within New Zealand that are the primary concern when implementing the provisions of the Commerce Act. The focus on New Zealand markets (consumers and producers) does not differentiate between domestic and foreign consumers or firms. The provisions of the Commerce Act operate regardless of who is operating in the market. ${ }^{41}$

The Commerce Commission’s publication “Guidelines to the Analysis of public benefits and detriments" (1994) provided that the "public" is the public of New Zealand and that

$39 \quad$ Ibid at $43-45$

40 This is not to say that their demands will not materially affect the design of New Zealand export products, or that product evolution represented by this design will, and has, not affected New Zealand's exports and terms of trade.

Section 4(1) of the Act provides:

This Act extends to the engaging in conduct outside New Zealand by any person resident or carrying on business in New Zealand to the extent that such conduct affects a market in New Zealand.

This clearly extends the coverage of the Act to conduct outside the borders of New Zealand provided there is an impact on a market in New Zealand. Therefore a foreign owned firm or foreign consumer is subject to the Commerce Act provided the conduct had an impact in a market in New Zealand. 
benefits to foreigners are to be counted only to the extent that they also involve benefits to New Zealanders. ${ }^{42}$ This publication (revised in 1997) no longer accurately records the Commission's view. ${ }^{43}$ The Commission has often cited the comments by the Court of Appeal in the AMPS-A decision ${ }^{44}$ as an authority on the treatment of benefits to foreign firms. ${ }^{45}$

Greig J, Brunt and Shaw (Lay Members) in that decision stated: ${ }^{46}$

We reject any view that profits earned by overseas investment in this country are necessarily to be regarded as a drain on New Zealand. New Zealand seeks to be a member of a liberal multilateral trading and investment community. Consistent with this stance, we observe that improvements in international efficiency create gains from trade and investment which, from a long-run perspective, benefit the New Zealand public... On the other hand, if there are circumstances in which the exercise of market power gives rise to functionless monopoly rents, supra-normal profits that arise neither from cost savings nor innovation, and which accrue to overseas shareholders, we think it right to regard these as exploitation of the New Zealand community and to be counted as a detriment to the public.

This position of the Court and the neutral treatment of consumers and producers is implicitly accepted in the recent High Court judgment of Hansen $\mathrm{J}$ and Vautier (Lay Member) on Air New Zealand and Qantas’ application for an alliance arrangement. ${ }^{47}$

In the AMPS-A decision the Court was suggesting that whether an efficiency defence to a merger or commercial practice will differ according to whether or not the relevant firm is foreign-owned turns upon the interpretation of functionless monopoly rents. If functionless refers to rents that have no implications for behaviour that is to the long-term benefit of consumers there will be only very limited possibilities of appeal to

42 The same position is taken by Pickford (1993).

43 The Review of the Commerce Act in 1992 resulted in a recommendation concerning this issue. The amendment was never made but the recommendation was that a section be inserted to the effect that:

Benefits which accrue outside of New Zealand but which create gains from trade and investment for New Zealand are regarded as benefits to the public.

$44 \quad$ Telecom Corporation of New Zealand Limited v Commerce Commission (1991) 4 TCLR 473.

45 See for example, Air NZ/Ansett/Bodas (decision 278, p 449), Powerco (decision 302, p 294),

Pohokura (decision 505, p 447), and Final Determination of Air NZ/Qantas p 907.

$46 \quad$ Ibid at 531.

$47 \quad$ Ibid 
discrimination on grounds of ownership in efficiency calculations. Absent regulatory barriers to entry, profits are the catalyst to competition, entry and innovation that enhances dynamic efficiency. If this function of profit is admitted under competition law there will be very few instances where foreign ownership discrimination is applicable. ${ }^{48}$ Alternatively, if the rents are statically treated as functionless, and their effect on competition and innovation ignored, there will be many examples of efficiency computations potentially materially affected by the Court's caveat. ${ }^{49}$

Even if profits were considered functionless and discrimination were contemplated it would have to be on the basis of incidence, in which case incidence-affecting issues should be considered before application of discrimination. These include the fact that the New Zealand (foreign) public may own some proportion of relevant foreign (domestic) firms, and these firms are generally liable to pay domestic taxes on any surplus earned in a New Zealand market: such taxes are a benefit to the public of New Zealand. ${ }^{50}$

Since competition law is a constraint on institutions of trade, including those of contracting, $^{51}$ its neutral application is required if the availability, enforceability and uptake of contracts is to be neutral as between domestic and foreign-owned firms. Indeed, the argument for the treatment of the long-term benefit of consumers, and efficiencies as dynamic efficiency with the total surplus criterion is the same as the rationale for security

\footnotetext{
48 It is noteworthy that among the myriad of cases where there is potential for foreign/domestic discrimination to arise - e.g. in Clear Corporation's repudiation of elements of its interconnection contract with Telecom Corporation of New Zealand Limited (see Evans and Quigley (2000)), and regulation of the telecommunications industry under the 2001 Telecommunications Act - it has not been introduced as a material factor in Court or regulatory proceedings in New Zealand.

49 The Commission seems to have adopted this view in its cost-benefit studies. For example, in the Authorisation of Pohokura joint marketing of gas the Commission argued that only because foreign ownership was on both sides of the market would it not discriminate on a foreign ownership basis in its counting of benefits and detriments. In the context of the High Court's position, this treatment is tantamount to suggesting that surpluses in the petroleum and gas exploration and field development industries held by foreign entities are inessential, in terms of the long-term benefit of consumers, to investment in those industries.

50 In the Commission's draft determination of its pipeline enquiry it treated surpluses accruing to domestic and foreign owned firms differently: in essence treating surpluses to foreign-owned firms as a detriment. No attempt was made to assess incidence in any detail. It ignored domestic taxes and whether or not the foreign owned firms were earning a "normal" return on their actual investment (as opposed to the Commission's assessment of what this investment "ought" to have been).
}

$51 \quad$ For example, see Evans and Quigley (2005). 
of contract. ${ }^{52}$ Unless contracts are impartially enforced transactions and investment will be affected. ${ }^{53}$ In particular if foreign-owned firms perceive that contracts are not enforceable in New Zealand they will either not transact in New Zealand or they will write into New Zealand contracts that they be enforceable in other jurisdictions. To treat firms within the same (New Zealand) market differently - under competition and/or contract law - according to domestic or foreign ownership would hamper dynamic efficiency because it would imply that existing foreign-owned firms in New Zealand would be discriminated against in administrative commerce decisions. ${ }^{54}$ If firms were fully informed of the discriminatory policy before they entered, fewer foreign-owner firms would enter and thereby competition and concomitantly the dynamic efficiency of New Zealand markets would be reduced. ${ }^{55}$ Where this inhibits the uptake and development of innovations the loss in welfare would, based on all the evidence, be very large. $^{56}$

The argument for enforcement of contracts - despite the existence of ex post outcomes that could be more efficient on a static efficiency basis - is that the limitation of opportunistic behaviour that is proscribed under enforceable contracts enhances dynamic efficiency. This is exactly the rationale for neutral treatment of domestically and foreign owned firms in efficiency tests under competition law and regulation.

52 See for example the discussions of Posner (1992, ch4) and Cooter and Ulen (2004, chs 6 and 7).

53 The central test for lawful commercial practices and arrangements under the Commerce Act is that of a likely substantial lessening of competition. In this context, there are two circumstances in which discriminating against foreign- relative to domestic-owned firms may arise. First, where there is doubt about the prospect of lessened competition, and even where there is no doubt, but benefits exceed some lessening of competition - as assessed in authorisations - a public benefit test is informative and influences decisions. Secondly, penalties for breaches of competition law should reflect damage to the public of New Zealand and these are indicated by the public benefits test. This was the position taken in the judgement of Commerce Commission v Caltex New Zealand Ltd [Penalty], (2000) 9 TCLR 366, 372 p 26-28. Even if determination of a breach does not entail discrimination, the penalty may well do so, and thereby induce discrimination against firms that are foreign-owned.

54 In fact, because the Commission discriminated against foreign ownership in its draftdetermination gas pipeline enquiry cost-benefit analysis, its public benefits test suggested that foreignowned firms should be regulated much more stringently than domestically-held firms. Rather than reexamine its definition of benefits and detriments the Commission (p. 171) suggested caution in applying the public benefits test.

55 Companies with listed shares are pressured to be productively efficient by the threat of takeover in the market for ownership and this is enhanced by the presence of foreign-owned firms. Indeed, in a small economy (potential) entry by foreign firms is a particularly important source of managerial and ownership competition.

$56 \quad$ See Goolsbee and Hausman op cit. 


\section{$4 \quad$ The Efficiency Test in New Zealand}

As trade and investment policies of most countries have liberalised over the past 20 years, there has been considerable convergence of competition and regulatory policies; fostered in part by international organisations such as the OECD and WTO. For this reason, and because the issues are similar, central elements of competition law are common to different countries. However, while the law is similar and techniques for its application almost identical, application does materially differ across countries. To the extent that there are substantive differences between countries on the basis of their size and location it is likely that implementation should be different even under the same statute. As Gal (2001) points out, the level of the US thresholds are simply not appropriate for small economies as they would create barriers to efficient mergers. Acceptance of the thesis that small isolated economies are different from large economies in their absence of economies of scale and necessarily more concentrated markets implies that, at a minimum, implementation of competition law would differ across countries. Emphasising the efficiency defense relatively more in smaller economies will permit the more restrictive competition law conditions of larger economies; which is likely to be dynamically efficient.

In addition, it is argued that the focus of competition authorities should shift from the structure of industry to the conduct of individual firms in the markets of modern economies. CRA (2002), and Shapiro (2002), for example, conclude that competition laws in new-economy markets should concentrate on removal of barriers to entry and its alleged effect on competition. They argue that the distinguishing feature of competition law for new-economy goods is that it should be applied with the objective of dynamic efficiency. Given this, it would be desirable to apply the efficiency defence on a case-bycase basis across the economy. ${ }^{57}$

\footnotetext{
${ }^{57}$ This does not mean that the competition authority may not develop rules of thumb about practices that go to dynamic efficiency and which limit case-by-case considerations. It might, for example, reach a presumption that long-term contracts by joint ventures in industries with much risk and sunk costs - e.g. in oil and gas exploration and production - will generally be efficient and therefore be readily authorised. For example, as it does now, the Commerce Act may permit certain actions among joint venture parties.
} 
Cooperation is important to efficiently deal with externalities that arise in areas such as innovation and standard setting. The ability to semi-formally co-ordinate is provided through joint ventures. There is a growing body of literature that argues that it is not efficient to limit coordination by per se offenses, as these impose direct and indirect inhibitions on potentially economically efficient coordination. ${ }^{58}$ This literature argues that rule of reason should apply, notwithstanding that monitoring and transaction costs of enforcement may be reduced by the per se approach. In small economies the issue is likely to be particularly acute because of the low population of firms in highly concentrated industries. In such circumstances any communication is likely to involve a significant share of the market and seem widespread. But to inhibit cooperation in such small markets is unlikely to be efficient.

It is likely that regulatory institutions have economies of scale that, of itself, imply that the average cost of socially desirable competition law enforcement will fall with the size of the economy, which may imply optimally relatively less activity. The complexity of the dynamic efficiency issues and the need to consider the avenue of efficiency defences - rule of reason - suggest a resource intensive regulatory authority. However, savings may be achieved in focussing on barriers to entry at the expense of market structure and static efficiency test thresholds.

In small isolated economies there can be expected to be a larger fraction of domestic markets that are concentrated. In these economies it is important that case-by-case application of the efficiencies criteria are applied to mergers and practices, particularly at the expense of rote application of competition rules of thumb derived from other jurisdictions. $^{59}$ The desirability of utilising economies of scale, perhaps by enabling exporting and enhancing dynamic efficiency means that the efficiency defense should be applied using the total surplus criterion. On similar grounds it is generally not desirable to distinguish between foreign and domestic entities in the efficiencies calculation. The

$58 \quad$ See Fershtman and Pakes op cit, by way of an example.

This is the position of Khemani (1991, 219). 
recent suggestions for the implementation of competition law in modern economies are designed to enhance dynamic efficiency and they are suited to direct application in small isolated economies.

The place and form of desirable competition law in any economy will depend upon the existing legal and political institutions of that country as well as more specific factors including those of size and location. Application of competition law that does not inhibit but enhances dynamic performance is a particular challenge for economies such as New Zealand with very small isolated domestic markets because domestic demand - and therefore domestic opportunity - is very limited and firms are extremely mobile in the modern world. This combination enhances the argument for competition law that enables dynamic efficiency and thereby the long term interest of New Zealand consumers. 


\section{References}

Amir (2001) "Market Structure Scale Economies and Industry Performance”, School of Economic Studies, University of Manchaester, mimeo.

Anandarup, Ray, 1984, Cost-Benefit Analysis: issues and methodologies, World Bank, Johns Hopkins, University Press.

Arnold T, D Boles de Boer, and L Evans (2003), “The Structure of New Zealand Industry and its Implications for Competition Law" Ch.1 of New Zealand Competition Law at the Turn of the Century, M Berry and L Evans eds., Victoria University of Wellington Press.

Baldwin, Robert E (2000) "Trade and Growth: Still Disagreement About the Relationships”, OECD Economics Department Working Paper, ECO/WKP.

Baumol, WJ (2002), The Free Market Innovation Machine: Analyzing the Growth Miracle of Capitalism. Princeton University Press.

Berry, M and M Pickford (2000) "A New Zealand Perspective on the Efficiencies Defence” ISCR Competition and Regulation Times, October 2000.

Boles de Boer, David, Christina Enright and Lewis Evans, 2000, “The ISP Markets of Australia and New Zealand”, INFO: the journal of policy, regulation and strategy for telecommunications, information and media, October, Vol 2(5), 2000,487-495.

Caves RE, ME Porter and AM Spence with JT Scott (1980), Competition in the Open Economy - A Model Applied to Canada, Cambridge Mass.: Harvard University Press.

CRA (2002), Innovation and Competition Policy - Part 1, Charles River Associates (United Kingdom) Ltd.

Cooter, Robert and Thomas Ulen (2004) Law and Economics, Pearson Addison Wesley Longman, $4^{\text {th }}$ ed..

Crandall, Robert, Allan T. Ingraham, and Hal J. Singer, 2004, "Do Unbundling Policies Discourage CLEC Facilities-Based Investment", The B.E. Journals in Economic Analysis \& Policy, 4(1), Article 14.

Dobbs, Ian M, 2004, “Intertemporal price cap regulation under uncertainty, Economic Journal, Vol 114, 421-440.

Evans, DS and R Schmalensee (2001) "Some Economic Aspects of Anti-Trust Analysis in Dynamically Competitive Industries” NBER Working Paper.

Evans, L 2004, “The New Economy: A Force for Competition or Market Power”, The 
New Economy: Challenges for East Asia and the Pacific, ch.7, P. Drysdale ed., Routledge Curzon.

Evans, Lewis T and Graeme A Guthrie, 2005, "Risk, price regulation, and irreversible investment,” International Journal of Industrial Organisation (forthcoming).

Evans, Lewis, and Patrick Hughes, (2003), Competition Policy in Small Distant Open Economies: Some Lessons from the Economics Literature, New Zealand Treasury Working Paper, 03/31.

Evans L, and N Quigley (2000) "Contracting Incentives for Breach and the Impact of Competition Law”, World Competition, Vol 23 (2), June.

Evans L, and N Quigley (2005) "The Interaction Between Contract and Competition Law", in Competition in the New Millenium , E Medalla ed, published under the auspices of the $28^{\text {th }}$ Pacific Trade and Development Conference, forthcoming.

Fershtman, C and A Pakes (2000) "A Dynamic Oligopoly with Collusion and Price Wars”, The RAND Journal of Economics, Vol 31(2), 207-236

Gal M.S. (2001) "Size Does Matter: the Effects of Market Size on Optimal Competition Policy" University of Southern California Law Review September.

Goolsbee, Austan, (2000) "In a World Without Borders: the Impact of Taxes on Internet Commerce”, Quarterly Journal of Economics, Vol 115(2), 561-576.

Hansmann, H (1996) The Ownership of Enterpise, Harvard University Press, Cambridge Mass.

Harberger, H (1954), “Monopoly and Resource Allocation,” American Economic Review Vol. 44.

Hausman, J (1997) "Valuing the Effect of Regulation on New Services in Telecommunications", Brookings Papers on Economic Activity, Microeconomics, 1-38, Head K and T Mayer (2000), "Non-Europe: The Magnitude and Causes of Market Fragmentation in the EU," mimeo, January.

Hoekman B, Kee HL and Olarreaga M (2001) "Entry Regulation and Trade: does Country Size Matter?” in World Development Report 2001 - Institutions for Markets, the World Bank, Washington.

Irvin, George, 1978, Modern Cost Benfit Methods: and introduction to financial, economic and social appraisal of development projects, MacMillan.

Jensen, MC and F Meckling (1976), "Value Maximisation, Stakeholder Theory, and the Corporate Objective Function”, Journal of Applied Corporate Finance, 4. 
Katz, Michael L (2004) “Competition, Efficiency and the Long-Term Benefit to EndUsers" (Annex D to the Telecom Submission to the Commerce Commission in respect of the Commerce Commission's Draft Report for its Schedule 3 Investigation into Regulation of Mobile Termination).

Khemani, RS (1991) "Merger Policies in Small vs Large Economies" in Competition Policy and Law at the Turn of the Century edited by RS Khemani and WT Stanbury, the Institute for the Research on Public Policy, Halifax, Nova Scotia.

Kessides, Ioannis N., 2004, Reforming infrastructure : privatization, regulation, and competition, World Bank, Washington, DC : World Bank.

Krishna P, 2003, “Are Regional Trading Partners Natural?”, Journal of Political Economy, Vol 111(1), 202-226.

Mas-Colell, Whinston, and Green (1995) Microeconomic Theory, Oxford University Press, New York.

Mathewson, F and N Quigley, (2003), "Market Power Thresholds: Theory and Competition Cases Related to Barriers to Entry", Ch. 6 of Competition Law at the Turn of the Century: a New Zealand perspective, Mark Berry and Lewis Evans eds. Victoria University Press.

Mathewson, F and R Winter, (2000), "The Analysis of Efficiencies in Superior Propane: Correct Criterion Incorrectly Applied”, Canadian Competition Record, Vol 20(2), 88-97.

Mishan, EJ (1963) “Welfare Criteria: are Compensation Tests Necessary?”, The Economics Journal, Vol 73, 342-350.

Mishan, EJ (1988) Cost-Benefit Analysis. (4th ed.). London: Unwin Hyman

Organisation for Economic Co-operation and Development (2002) Competition, Innovation and Productivity Growth: A Review of the Theory and Evidence, Economics Department Working Papers No 317.

Pickford, $M$ "The Evaluation of Public Benefit and Detriment Under the Commerce Act 1986, New Zealand Economic Papers, 27(2), 1993, 209-231.

Posner, R (1992) Economic Analysis of Law, Little Brown and Company, $4^{\text {th }}$ ed..

Ratnayake, Ravi (1999) "Industry Concentration and Competition: New Zealand Experience”, International Journal of Industrial Organisation, Vol 17(7), 1041-57.

Shapiro, Carl (2002), Competition Policy in Perspective, OECD working paper.

Stigler, George J (1951) “The Division of Labour is Limited by the Extent of the Market”, The Journal of Political Economy, LIX(3), 185-193. 
Trebilcock, MJ (1991) "Competition Policy, Trade Policy and the Problem of Second Best" in Competition Policy and Law at the Turn of the Century edited by RS Khemani and WT Stanbury, the Institute for the Research on Public Policy, Halifax, Nova Scotia

Trebilcock, M.J . (2004) The Great Efficiencies Debate in Canadian Merger Policy, New Zealand Business Law Quarterly, 10(), 298-325.

Tullock, G (1967), “The Welfare Costs of Tariffs, Monopolies and Trusts,” Western Economic Journal, Vol 5.

Williamson, OE (1968) "Economies as an Antitrust Defense: The Welfare Tradeoffs," American Economic Review 58: 18-36.

World Bank, 2000, Reforming Public Institutions and Strengthening Governance, Public Sector Group, Poverty Reduction and Economic Management (PREM) Network, The World Bank, November. 